\title{
IMPLEMENTASI METODE STIFIn DALAM MENINGKATKAN KEMAMPUAN MENGHAFAL AL-QUR'AN DI RUMAH QUR'AN STIFIn PAITON PROBOLINGGO
}

\author{
Akmal Mundiri \& Irma Zahra \\ (Universitas Nurul Jadid Paiton Probolinggo)
}

\begin{abstract}
Abstrak:
Al-Qur'an sebagai salah satu pedoman yang mewartakan prinsip dan doktrin ajaran Islam mempunyai apa yang disebut dengan kepastian teks (qat'i al-wurud). Dalam proses menjaga kepastian teks tersebut, terdapat peran serta manusia yang salah satu caranya dengan menghafalkan alQur'an. Namun, menghafal al-Qur'an tidak semudah yang dibayangkan sebagaimana menghafal suatu lagu atau syair. Problem yang dihadapi oleh seseorang yang sedang menghafal al-Qur'an memang banyak dan bermacam-macam. Mulai dari faktor minat, bakat, lingkungan, waktu, sampai pada metode menghafal itu sendiri. Metode STIFIn sebagai salah satu metode menghafal al-Qur'an dalam implementasinya menawarkan solusi menghafal cepat yang dilakukan mulai sebelum proses menghafal. Hasil penelitian ini menunjukkan bahwa dalam implementasinya, dengan cara memetakan penghafal berbasis pada teori hereditas, sehingga berimplikasi pada rekayasa pembelajaran yang berbeda antar masingmasing potensi. Demikian pula dengan tes kemampuan hafalan guna mengetahui kekuatan dan kemampuan masing-masing dalam menghafal alQur'an. Hal tersebut kemudian diikuti dengan klasifikasi penghafal alQur'an berdasarkan teori sirkulasi STIFIn ketika melaksanakan kegiatan setoran kepada pembina, sehingga dalam pelaksanaan metode STIFIn sangat membantu santri untuk bisa menghafal al-Qur'an dengan lebih mudah dan nyaman, karena menyesuaikan metode dengan potensi genetik masing-masing.
\end{abstract}

Kata Kunci: Metode STIFIn; Menghafal Al-Qur'an; Genetik. 


\begin{abstract}
:
Al-Qur'an as one of the guidelines that proclaim the principles and doctrines of Islamic teachings has what is called the certainty of the text (qat'i al-wurud). In the process of maintaining the certainty of the text, there is the human role that as memorizer of the holy Qur'an. However, memorizing the Qur'an is not easy as imagined as memorizing a song or poem. The problem faced by someone who is memorizing the Qur'an is many and varied. Starting from the interest factor, talent, environment, time, until the method of memorizing itself. The STIFIn method as one of the methods of memorizing the Qur'an in its implementation offers a solution to memorize quickly that began before the memorization process. The results of this study indicate that in its implementation, by mapping the memorizers based on the theory of heredity, so that it implies different learning engineering between each potential. Similarly, the tests of the ability of memorizing to know the strength and ability each person in memorizing the Holy Qur'an. It is then followed by the classification of the who memorized the Qur'an based on the STIFIn circulation theory when carrying out the deposit activities to each coach, so in the implementation of STIFIn method is very helpful for santri to be able to memorize the Qur'an more easily and comfortably, because have adjusted the method with their respective genetic potential.
\end{abstract}

Keywords: STIFIn Method; Memorizing Al-Qur'an; Genetic.

\title{
A. Pendahuluan
}

Dewasa ini, menghafal al-Qur'an bukanlah hal yang tabu bagi sebagian umat muslim. Berbagai event lomba hafalan al-Qur'an marak dilaksanakan di berbagai acara bahkan di beberapa stasiun televisi terkenal yang secara rutin mengadakan tayangan perlombaan tahfidzul Qur'an pada bulan suci ramadhan dimana pesertanya diikuti mulai dari tingkat anak-anak hingga dewasa. Menghafal al-Qur'an adalah sebuah upaya untuk memudahkan seseorang dalam memahami dan mengingat isi-isi al-Qur'an dan untuk menjaga keautentikannya serta menjadi sebuah amal shaleh bagi umat Islam. Adapun salah satu penjagaan Allah SWT terhadap Al-Qur`an adalah dengan memuliakan para penghafalnya. Nabi Muhammad pernah bersabda akan keutamaan bagi penghafal al-Qur'an sebagaimana berikut:

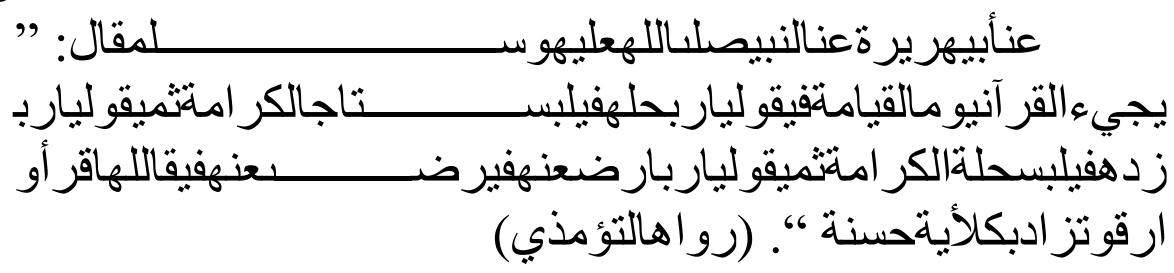

Jurnal Pendidikan Agama Islam (Journal of Islamic Education Studies)

Volume 5 Nomor 2 (2017)

ISSN(p) 2089-1946\& ISSN(e) 2527-4511

Hal. 202 - 223 
"Penghafal al-Qur`an akan datang pada hari kiamat, kemudian al-Qur`an akan berkata: 'Wahai Tuhanku, bebaskanlah dia.' Kemudian orang itu dipakaikan mahkota karamah (kehormatan). al-Qur'an kembali meminta: 'Wahai Tuhanku tambahkanlah.' Maka, orang itu dipakaikan jubah karamah. Kemudian al-Qur`an memohon lagi: 'Wahai Tuhanku, ridhailah dia.' Maka Allah SWT meridha nya. Dan diperintahkankepada orang itu: 'Bacalah dan teruslah naiki (derajat-derajat surga).' Dan Allah SWT menambahkan dari setiap ayat yang dibacanya tambahan nikmat dan kebaikan. (HR. Tirmidzi). ${ }^{1}$

Dengan nikmat dan kemuliaan tersebutlah yang menyebabkan umat muslim berlomba-lomba dalam menghafalkan al-Qur'an. Namun menghafal alQur'an tentu tidak semudah menghafalkan lagu dan syair. Dalam proses menghafal al-Qur'an suatu metode sangatlah penting agar tujuan yang diharapkan dapat tercapai. Tanpa metode maka suatu pembelajaran akan sia-sia, begitu juga dengan menghafal al-Qur'an. Metode menghafal al-Qur'an adalah cara atau jalan yang harus dilalui atau ditempuh dalam proses menghafal al-Qur'an agar dapat menghafal dengan baik dan lancar. Problem yang dihadapi oleh seseorang yang sedang menghafal al-Qur'an memang banyak dan bermacammacam. Mulai dari faktor minat, bakat, lingkungan, waktu, sampai pada metode menghafal itu sendiri. Namun pada pembahasan ini, yang menjadi suatu permasalahan adalah ketika seseorang menghafal menggunakan cara yang tidak sesuai dengan sistem kinerja otak, pada akhirnya akan menyebabkan hafalan mudah lupa bahkan orang tersebut merasa tertekan selama proses menghafal. Ini dapat disebabkan karena setiap manusia memiliki sistem kinerja otak dan kepribadian yang berbeda-beda, maka memerlukan penanganan yang berbedabeda pula sesuai dengan kinerja otak masing-masing dalam proses menghafal alQur'an.

Di Pondok Pesantren Nurul Jadid khususnya wilayah Al-Mawaddah Paiton Probolinggo, kini telah menjadi salah satu tempat cabang rumah AlQur'an STIFIn, dimana dalam proses menghafalnya menggunakan suatu metode berdasarkan konsep STIFIn yang berkaitan dengan sistem kinerja otak atau yang dikatakan dengan mesin kecerdasan masing-masing anak. Dibukanya rumah Qur'an STIFIn yang memiliki target capaian 8 bulan ini dilatar belakangi oleh keinginan pemangku wilayah al-Mawaddah untuk memberikan wadah bagi santri pondok pesantren Nurul Jadid maupun luar pondok yang ingin menghafalkan al-Qur'an secara fokus, tanpa ada kegiatan sambilan di lembaga lainnya dengan menggunakan metode STIFIn. Metode STIFIn ini merupakan penerapan dari konsep STIFIn yang mengkompilasi dari teori-teori psikologi,

${ }^{1}$ Abi Isa Muhammad bin Isa bin Saurah al-Tirmidzi, Jami' al-Tirmidzi (Riyadl: Bait al-Afkar, t.t), 465. 
neuroscience, dan ilmu sumberdaya manusia. Prinsip besarnya mengacu kepada konsep kecerdasan tunggal dari Carl Gustaav Jung. Cara mengetahui mesin kecerdasan ini dengan STIFIn Fingerprint, sebuah tes yang dilakukan dengan cara men-scan kesepuluh ujung jari untuk mendapatkan sidik jari dengan alat fingerprint. Sidik jari yang membawa informasi tentang komposisi susunan syaraf tersebut kemudian dianalisa dan dihubungkan dengan belahan otak tertentu yang dominan berperan sebagai sistem operasi dan sekaligus menjadi mesin kecerdasan seseorang. Menurut konsep STIFIn, bukan belahan otak yang memiliki kapasitas paling besar yang dianggap dominan, melainkan yang kerap digunakan, paling aktif berfungsi, paling otomatis digunakan, dan menjadi bawah sadar manusia. Konsep STIFIn menyebutnya sebagai sistem operasi otak yang terdiri dari kecerdasan sensing, thinking, intuiting, feeling, dan insting. Mengingat, urgensi sistem operasi otak sebagaimana dijelaskan di atas, maka pembahasan tentang implementasi metode STIFIn yang berbasis sistem operasi otak dalam pembelajaran dan menghafal al-Qur'an menjadi cukup penting untuk dibahas sebagai upaya diseminasi pengetahuan tentang metode menghafal al-Qur'an dengan cepat.

\section{B. Metode Pembelajaran Al-Qur'an Berbasis Sistem Operasi Otak dalam Konsep STIFIn}

Metode merupakan cara sistematis dan terfikir secara baik untuk mencapai tujuan, prinsip, dan praktik-praktik pengajaran. ${ }^{2}$ Sunhaji mengemukakan bahwa metode berasal dari bahasa Yunani yaitu methodos yang berasal dari kata "meta" dan "hodos". Kata meta berarti melalui sedangkan kata hodos berarti jalan, sehingga metode berarti jalan yang harus dilalui, cara melakukan sesuatu atau prosedur. ${ }^{3}$ Sedangkan menurut Novan Ardi W, metode dalam bahasa Arab dikenal dengan istilah thariqah yang berarti langkah-langkah yang diambil seorang pendidik guna membantu peserta didik merealisasikan tujuan tertentu. ${ }^{4}$ Metode adalah cara yang digunakan untuk mengimplementasikan rencana yang sudah disusun dalam kegiatan nyata agar tujuan yang telah disusun tercapai secara optimal. ${ }^{5}$

Metode merupakan suatu teknik penyampaian bahan pelajaran kepada murid yang dimaksudkan agar murid dapat menangkap pelajaran dengan

2 R. SuyotoBakir, Kamus Lengkap Bahasa Indonesia (Batam: Karisma Publising Group, 2006), 380.

${ }^{3}$ Sunhaji, Strategi Pembelelajaran (Purwokerto: Stain Press, 2012), 38.

${ }^{4}$ Novan Ardi Wiyanidan Bernawi, Ilmu Pendidikan Islam: Rancang Bangun Konsep Pendidikan Monokotomik-Holistik (Yogyakarta: Ar-Ruzz Media, 2012), 185.

5 Wina Sanjaya, Strategi Pembelajaran Berorientasi Standar Proses Pendidikan (Jakarta: Kencana, 2006), 147.

Jurnal Pendidikan Agama Islam (Journal of Islamic Education Studies)

Volume 5 Nomor 2 (2017)

ISSN(p) 2089-1946\& ISSN(e) 2527-4511

Hal. 204 - 223 
mudah, efektif, dan dapat dicerna oleh anak dengan baik. ${ }^{6}$ Makin baik sebuah metode, makin efektif pula fungsinya sebagai alat pencapaian tujuan. Menurut Syaiful Bahari Djamarah, keanekaragaman metode pembelajaran disebabkan oleh pengaruh berbagai faktor, di antaranya: (1) Tujuan dengan berbagai jenis dan fungsinya; (2) Peserta didik dengan berbagai tingkat kematangannya; (3) Situasi dalam pembelajaran dengan berbagai keadaanya; (4) Fasilitas yang mendukung pembelajaran dengan berbagai kualitas dan kuatitasnya; (5) Pribadi guru serta kemampuan profesionalitas yang berbeda-beda. ${ }^{7}$

Dari keterangan di atas dapat diperoleh suatu pengertian metode yang berupa cara mengajar yang telah disusun berdasarkan prinsip dan sistem tertentu. Sedangkan pembelajaran menurut Gagne sebagaimana dikutip oleh Benny A. Pribadi mendefinisikan istilah pembelajaran sebagai "a set of events embedded in purposeful activities that facilitate learning" yang mempunyai makna bahwa pembelajaran merupakan serangkaian aktivitas yang sengaja diciptakan dengan maksud untuk memudahkan terjadinya proses belajar. Benny A. Pribadi menjelaskan bahwa pembelajaran adalah proses yang sengaja dirancang untuk menciptakan terjadinya aktivitas belajar dalam arti diri individu, dengan kata lain pembelajaran merupakan sesuatu hal yang bersifat eksternal dan sengaja dirancang untuk mendukung terjadinya proses belajar internal dalam diri individu. ${ }^{8}$

Pembelajaran, berasal dari "belajar" yang berarti proses atau cara menjadikan orang atau makhluk hidup belajar. Kata belajar ditambahi imbuhan "pe-an" menjadi pembelajaran yang berartu suatu proses, perbuatan, atau usaha untuk belajar. Menurut Sunhaji Pembelajaran adalah sesuatu usaha untuk membuat siswa belajar sehingga situasi tersebut merupakan peristiwa belajar (event of learning), yang berupa usaha dalam terjadinya perubahan tingkah laku pada diri siswa. Pada intinya pembelajaran adalah sebuah interaksi antara guru dan murid dalam kegiatan belajar mengajar. ${ }^{9}$ berdasarkan uraian definisidefinisi tersebut, maka metode pembelajaran al-Qur'an adalah suatu cara pembelajaran al-Qur'an dengan menggunakan segala aspek proses belajar mengajar sehingga mendapatkan perubahan-perubahan yang lebih baik dalam kemampuan memahami al-Qur'an.

${ }^{6}$ Zakiah Daradjat, Metodologi Pengajaran Agama Islam (Jakarta: Bumi Aksara,1996), 61.

${ }^{7}$ Syaiful Bahri Djamarah, Guru dan Anak Didik dalam Interasksi Edukatif (Jakarta: Rineka Cipta, 2010), 222-223.

8 Benny A. Pribadi, Model Desain Sistem Pembelajaran (Jakarta: Dian Rakyat,2011), 9-10.

${ }^{9}$ Sunhaji, Pembelajaran Tematik Integrative Pendidikan Agama Islam dan Sains (Purwokerto: Stain Press, 2013), 17. 
Adapun sejarah perjalanan konsep STIFIn dimulai kurang lebih 13 tahun yang lalu, lebih tepatnya pada tahun 1999, ketika Farid Poniman bersama partner-nya, Indrawan Nugroho, yang kemudian diikuti oleh Jamil Azzaini mendirikan lembaga training Kubik Leadership. Lembaga training tersebut setiap memulai program trainingnya terlebih dahulu memetakan peserta training sesuai dengan jenis kecerdasannya. Sebagai konsep, STIFIn kala itu dapat dibilang masih embrio. Dalam perjalanannya, perbaikan konsep dilakukan disana-sini seiring dengan berkembangnya penyelenggaraan training Kubik Leadership. Namun, kala itu, tesis atau hipotesisnya sudah matang dan kukuh bahwa manusia memiliki kecerdasan genetik. Berapa persisnya, itulah yang disebut terus dengan proses transformasi yang berkesinambungan. Pada awalnya, Farid Poniman menggunakan empat kecerdasan yakni S, T, I, dan F seperti kita dapat baca dalam buku best seller Kubik Leadership. Pergulatan intelektual dan penyempurnaan terus dilakukan oleh Farid Poniman, sebelum terbitnya buku ke DNA Sukses Mulia yang akhirnya berujung pada penemuan kecerdasan ke lima, yakni In. Sekarang STIFIn sudah final dengan 5 mesin kecerdasan dan 9 personality genetik. Dengan demikian, bahwa tidak akan ada lagi jenis kecerdasan ke-6 dan tidak akan ada personaliti genetik yang ke-10.10

Setelah dilakukan riset untuk sekian lama, kini konsep STIFIn sudah sangat kokoh. Kekuatan utamanya terletak pada konsep yang simpel, akurat, serta aplikatif.11 Jadi, konsep STIFIn memetakan dari 5 belahan otak manusia, 1 yang menjadi dominan. Menjadi pengendali manusia, pembentuk bakat alaminya. STIFIn adalah uraian dari sensing (disingkat S), thinking (disingkat T), intuiting (disingkat I), feeling (disingkat F), insting (disingkat In). Dalam konsep tersebut, Farid Poniman memetakan gaya belajar masing-masing sebagai berikut: 12

1. Sensing memiliki gaya belajar menghafal, kebiasaan bermain, kehebatan pada otot, fokus pada pelajaran, kunci sukses dengan meningkatkan frekuensi, sumber kekuatannya otot, fungsi tubuh pada muskuler, konstitusi tubuhnya atletis, DNAnya adenin, stimulus jenis darahnya AB, dan kemistri dirinya tanah sehingga cenderung pada harta dengan peran sosial yang stabil, dan menyimpan kekayaan. Cara belajar terbaik sensing adalah dengan mencontoh. Menggunakan panca indera untuk merekam bagaimana orang terbaik melakukannya, kemudian mencontoh. Melakukan upcopy jika memungkinkan, memperbanyak jam terbang, semakin sering melakukannya

\footnotetext{
${ }^{10}$ Farid Poniman \& Rahman Adi Mangussara, Konsep Palugada (Jakarta: STIFIn Institute, 2013), 1.

11Poniman \& Mangussara, KonsepPalugada, 1-2.

12Poniman \& Mangussara, KonsepPalugada, 2.

Jurnal Pendidikan Agama Islam (Journal of Islamic Education Studies)

Volume 5 Nomor 2 (2017)

ISSN(p) 2089-1946\& ISSN(e) 2527-4511

Hal. 206 - 223
} 
maka semakin mahir. Mulai dari yang kecil-kecil lalu melakukan peningkatan secara incremental.

2. Thinking memiliki gaya belajar menghitung, kebiasaannya serius, kehebatan pada logika, fokus pada persahabatan, kunci suksesnya dengan menyusun prioritas, sumber kekuatannya tulang, fungsi tubuhnya cerebral, konstitusi tubuhnya piknis, DNAnya guanin, stimulus jenis darahnya A, kemistri dirinya besi sehingga cenderung ke tahta dengan peran sosial pada kekuasaan, tegas, dan mandiri. Cara belajar terbaik thinking adalah dengan menggunakan kemampuan otak kirinya untuk menganalisa. Melakukan observasi terhadap sebuah proses kerja atau tugas, kemudian menemukan kelemahannya, memperbaiki dan melihat hasilnya. Diulangi terus hingga melihat hasil yang positif. Mempelajari buku manual, melihat dan menguasai struktur dan prosesnya. Menggunakan sebanyak mungkin data untuk menyempurnakan analisa.

3. Intuiting memiliki gaya belajar mempolakan, kebiasaannya usil, kehebatannya adalah kreatif, fokus pada imajinasi, kunci suksesnya memperbaiki kualitas, sumber kekuatan pada pencernaan, fungsi tubuhnya digestif, konstitusi tubuhnya asthenis, DNAnya timin, stimulus jenis darahnya $B$, kemistri dirinya kayu sehingga cenderung ke kata dengan peran sosialnya kreatif, berkelas, berilmu, dan berpengaruh dalam kata. Cara belajar terbaik intuiting adalah dengan menggunakan kemampuan otak kanannya dalam mencari ide dan pola. Ide dan pola dapat ditemukan dari mana saja, buku, film, majalah, atau televisi. Selalu mencari hal yang baru dari apa yang dilihat, didengar, atau dibaca. Menemukan pola dari apa yang sudah dipelajari dan menghubungkan dengan ilmu yang ingin dikuasai. Imajinasi dan kreativitas adalah modal terbesarnya.

4. Feeling memiliki gaya belajar mendengarkan, kebiasaannya santai, kehebatan dalam berbicara, fokus pada peranan, kunci suksesnya memimpin diri, sumber kekuatannya pernafasan, fungsi tubuhnya respiratoris, konstitusi tubuhnya displastis, DNAnya sitosin, stimulus jenis darahnya 0 , kemistri dirinya api sehingga cenderung ke cinta dengan peran sosial yang berkobar, mood, dan perasaan cinta. Cara belajar terbaik feeling adalah melalui orang. Mendapatkan inspirasi atau pemahaman melalui orang lain. Memperbanyak aktivitas diskusi, khususnya dengan orang-orang yang menguasai ilmu yang hendak dikuasai. Memilih buku-buku, artikel, atau biografi yang terkait dengan orang-orang tersebut dan menemukan bagaimana mereka mengaplikasikan ilmu tersebut.

5. Instinct memiliki gaya belajar merangkum, kebiasannya ikut campur, kehebatannya serba dapat, fokus pada penampakkan, kunci suksesnya 
menolong teman, sumber kekuatannya keseimbangan, fungsi tubuhnya sirkuler, konstitusi jasmaninya stenis, DNAnya seimbang antara adenin, guanin, timin dan sitosin, stimulus jenis darahnya di antara AB, A, B dan O, kemistri dirinya air sehingga cenderung bahagia dengan peran sosial pada perdamaian (juru damai) dan kebahagiaan. Cara belajar terbaik instinct adalah dengan merespon secara cepat dan spontan kebutuhan yang dituntut dari sebuah keadaan, terutama yang terkait dengan ilmu yang ingin dikuasai. Keserbabisaan akan sangat membantu cara belajar. Menggunakan kelebihan dalam hal kesediaan untuk berkorban, dengan menolong orang lain mengerjakan pekerjaan yang memerlukan ilmu/keterampilan yang ingin dikuasai.

Konsep STIFIn diperkenalkan oleh Farid Poniman dengan mengkompilasi dari berbagai teori psikologi, neuroscience, dan SDM. Prinsip besarnya mengacu kepada konsep kecerdasan tunggal dari C.G Jung. Tes yang dilakukan dengan cara men-scan kesepuluh ujung jari (mengambil waktu tidak lebih dari satu menit). Sidik jari yang membawa informasi tentang komposisi susunan syaraf tersebut kemudian dianalisa dan dihubungkan dengan belahan otak tertentu yang dominan berperan sebagai sistem operasi dan sekaligus menjadi jenis kecerdasan. Bahkan dari susunan syaraf tersebut masih dapat diprediksi letak dominasi mesin kecerdasan yang ada di lapisan otak berwarna putih atau di lapisan otak berwarna abu-abu.13

Tes sidik jari STIFIn mampu membedakan bakat mesin kecerdasan dan personality seseorang yang genetik secara nyata. Bahkan susunan syaraf tersebut masih dapat diprediksi letak dominasi mesin kecerdasan yang dikemudikan dengan dua cara yang berbeda yaitu: kemudi introvert (i) atau ekstrovert (e). Mesin kecerdasan dengan kemudi i atau e itulah yang kemudian disebut dengan personality. Tes mesin atau karakter kecerdasan STIFIn Personality merupakan tes mengenali mesin keceradasan yang dominan dimiliki oleh peserta didik.

Pada dasarnya setiap peserta didik memiliki karakter kecerdasan yang dominan. Karakter yang dominan itulah yang menjadi kekuatan utama untuk meningkatkan prestasi belajar. ${ }^{14}$ Inilah yang selanjutnya penting bagi peserta didik untuk mengetahui potensi/kekuatan yang ada pada dirinya dalam mengoptimalkan kemampuan.

\section{Memori dan Kemampuan dalam Menghafal Al-Qur'an}

Kata menghafal dari kata hafal yang artinya telah masuk di ingatan atau dapat mengucapkan diluar kepala (tanpa melihat buku atau catatan lain).

\footnotetext{
${ }^{13}$ Farid Poniman, Penjelasan Hasil Tes STIFIn (Bekasi: STIFIn Fingerprint, 2012), Cet. ke-5, iv.

${ }^{14}$ Farid Poniman, dkk, Kubik Leadership (Jakarta: Gramedia Pustaka Utama, 2008), 4.

Jurnal Pendidikan Agama Islam (Journal of Islamic Education Studies)

Volume 5 Nomor 2 (2017)

ISSN(p) 2089-1946\& ISSN(e) 2527-4511

Hal. 208 - 223
} 
Sedangkan menghafal artinya berusaha meresapkan ke dalam pikiran agar selalu ingat. ${ }^{15}$ Pengertian al-Qur'an secara bahasa adalah bacaan, karena kata al-Qur'an adalah bentuk masdar dari fiil madhi قر - يقر- قر . Sedangkan pengertian al-Qur'an secara istilah adalah kalam Allah SWT yang diturunkan ke hati Nabi Muhammad SAW secara berangsur-angsur dalam bentuk ayat-ayat dan surat-surat selama fase kerasulan (23 tahun), dimulai dari surat Al-Fatihah dan di akhiri dengan surah an-Nas, disampaikan secara mutawatir mutlak, sebagai bukti kemu'jizatan atas kebenaran risalah Islam. ${ }^{16}$ Dapat ditarik kesimpulan bahwa kemampuan menghafal al- Qur'an adalah proses melafalkan dan meresapkan ayat-ayat alQur'an dalam pikiran agar dapat diingat dan lancar melafalkannya diluar kepala.

Dalam menghafal al-Qur'an, proses yang dijalani tidaklah mudah dan bahkan memakan waktu yang cukup lama bergantung pada kekuatan memori penghafal al-Qur'an. Dalam hal ini, dikatakan tidak mudah karena yang dihafalkan dari sisi kuantitas yang tidak sedikit dan setidaknya terdiri dari 114 surat, 6.236 ayat, 77.439 kata, dan 323.015 huruf. Oleh karena itu, kekuatan memori yang ditunjang oleh personality merupakan hal yang sangat urgen dalam proses ini. Di samping itu, setelah penghafal al-Qur'an menghafalnya, maka yang bersangkutan dihadapkan pada kewajiban dalam menjaga hafalannya. ${ }^{17}$ Sehingga bagi penghafal al-Qur'an, proses retrieval memori hafalannya tidak hanya dalam kategori short term memory. Namun yang terpenting adalah retrieval dalam kategori long term memory.

Demikian pentingnya kekuatan memori dalam menghafal al-Qur'an sehingga dalam upaya penguatan tentunya juga dibutuhkan suatu upaya dalam menjaga kesehatan otak yang akan berdampak positif terhadap memori dalam otak. Upaya menjaga kesehatan otak tersebut dapat dilakukan dengan latihan fisik dan kegiatan yang mampu menstimulasi otak. Demikian pula dengan makanan yang sehat, kemampuan dalam mengelola stres, suplemen vitamin, tidur malam yang cukup, asam lemak omega-3, dan makanan lainnya yang menunjang kesehatan otak. ${ }^{18}$

Memori berkaitan erat dengan proses belajar sehingga jika dikaitkan dengan menghafal al-Qur'an maka proses mengenal dan memahami melalui panca indera yang selanjutnya diubah menjadi simbol-simbol tertentu (encoding). Setelah proses encoding maka dilakukan proses penyimpanan

15 Tim Penyusun Kamus Pusat Pembinaan dan Pengembangan Bahasa, Kamus Besar Bahasa Indonesia (Jakarta: Balai Pustaka, 1989), 291.

${ }^{16}$ Abdul Shabur Syahin, Saat al Qur'an Butuh Pembelaan (Jakarta: Erlangga, 2006), 2.

${ }^{17}$ Lisya Chairani dan M.A. Subandi, Psikologi Santri Penghafal al-Qur'an; Peranan Regulasi Diri (Yogyakarta: Pustaka Pelajar, 2011), 2-3.

${ }^{18}$ Gita Sekar Prihantini, Strategi Belajar (Malang: UMM Press, 2015), 361. 
(storage). Bagian penyimpanan ini yang menurut Prihantini disebut dengan lobus temporalis, hipokampus, dan amigdala yang termasuk dalam sistem limbik dalam otak. ${ }^{19}$ Dengan demikian, dapat dikatakan bahwa memori dalam proses menghafal al-Qur'an berfungsi untuk menerima, menyimpan, dan memproduksikan informasi ketika proses retrieval.

Proses mengingat dalam menghafal al-Qur'an berkaitan erat dengan memori, sehingga memungkinkan penghafal al-Qur'an dalam menyimpan hafalan untuk diingat kembali dalam beberapa saat kemudian atau untuk jangka waktu panjang. Dalam pembagiannya, memori terbagi menjadi memori verbal (otak kiri dan memori visual (otak kanan). ${ }^{20}$ Dalam memori terdapat struktur ingatan, yang dalam pembahasan tentang memori dapat dibedakan menjadi tiga sistem ingatan; 1) sistem ingatan sensorik, 2) sistem ingatan jangka pendek(short term memory), dan 3) sistem ingatan jangka panjang (long term memory). Memori sensorik berfungsi mencatat stimuli yang masuk melalui panca indera. Jika stimuli tersebut tidak diperhatikan maka akan segera hilang dan terlupakan. Namun sebaliknya jika mendapat perhatian maka stimuli tersebut akan ditransfer ke memori jangka pendek yang hanya mampu menyimpan stimuli atau informasi selama 30 detik saja. Selanjutnya, stimuli yang telah direkam dalam memori jangka pendek dapat ditransfer ke memori jangka panjang. Jika berhasil dalam proses retrieval memori jangka panjang, maka penghafal alQur'an seakan-akan hidup dalam dua masa, masa saat menghafal dan masa saat ini (ketika proses retrieval berlangsung) ${ }^{21}$.

\section{Implementasi Metode STIFin dalam Meningkatkan Kemampuan Menghafal Al-Qur'an}

Berdasarkan hasil penelitian yang dilakukan di Rumah Qur'an STIFIn Paiton Probolinggo, yang berlokasi di wilayah Al-Mawaddah Pondok Pesantren Nurul Jadid Paiton Probolinggo dapat dikemukakan bahwa implementasi metode STIFIn dalam meningkatkan kemampuan menghafal al-Qur'an dilakukan dengan:

1. Diawali dengan tes potensi genetik

Tes potensi dalam implmentasi metode ini dilakukan dengan tes sidik jari atau DNA yang mana berkaitan dengan teori hereditas. Hereditas merupakan kekuatan yang terbawa atau diturunkan oleh generasi tua kepada generasi muda melalui plasma benih atau gen. Aspek-aspek yang diturunkan oleh orangtua kepada anak-anaknya adalah potensi intelektual, kepribadian, dan biologis. Ada beberapa prinsip hereditas yang perlu

\footnotetext{
${ }^{19}$ Prihantini, Strategi Belajar, 362.

${ }^{20}$ Prihantini, Strategi Belajar, 363.

${ }^{21}$ Magda Bhinnety, "Struktur dan Proses Memori”, Buletin Psikologi, Vol. 16, No. 2, (2008), 74-88.

Jurnal Pendidikan Agama Islam (Journal of Islamic Education Studies)

Volume 5 Nomor 2 (2017)
}

ISSN(p) 2089-1946\& ISSN(e) 2527-4511

Hal. 210 - 223 
diketahui, yaitu:22 Pertama, prinsip reproduksi. Prinsip ini menyatakan bahwa ciri-ciri yang diperoleh orang tua dari belajar tidak akan diturunkan kepada anak-anaknya. Kedua, prinsip konformitas. Bahwa tiap-tiap jenis atau golongan (spesies) akan menghasilkan jenisnya sendiri. Misalnya, jenis manusia akan menghasilkan manusia lagi bukan jenis yang lain (binatang atau tumbuhan).

Ketiga, prinsip variasi. Bahwa setiap individu merupakan perpaduan antara gen yang dibawa oleh ayah dan ibunya. Hal ini yang meenjadi penentu perbedaan individual setiap orang. Keempat, prinsip regresi filial. Menurut Francis Galton regresi filial merupakan sifat-sifat dari orangtua akan menghasilkan keturunannya dengan kecenderungan kepada sifat rataratanya.

Berbicara mengenai potensi genetik, mungkin akan menghadapi perdebatan klasik mengenai kepribadian manusia dalam dunia psikologi ataupun human resoures. Perdebatan dua world-view, tentang mana yang lebih mempengaruhi kepribadian seseorang: genetic atau lngkungan (nature or nurture)? Persoalan ini telah menjadi salah satu pusat perhatian ilmu psikologi selama beberapa dekade belakangan ini, yang berujung pada kesimpulan sementara, bahwa diri manusia seara perilaku dikendalikan $50 \%$ oleh gen sisanya oleh lingkungan di mana kita hidup. Sebagaimana rumus karakteristik manusia yang berlaku saat ini: ${ }^{23}$

\section{Gambar 1: Rumus Karakteristik Manusia}

\section{Fenotif $(100 \%)$ = Genetik $(20 \%)+$ Lingkungan $(80 \%)$}

Fenotif merupakan gambaran siapa diri manusia seutuhnya, yang berupa hasil dari interaksi Genetik yang berkontribusi sekitar 20\% dan lingkungan yang berkontribusi sekitar 80\%. Meskipun faktor tempaan lingkungan berkontribusi jauh lebih besar dibanding faktor genetik, namun yang perlu menjadi perhatian besar adalah kenyataan bahwa: genetic bersifat tetap, stabil, dan tidak berubah (sejak lahir hingga akhir hayat). Sedangkan lingkungan bersifat fleksibel, tidak stabil, dan berubah-ubah. Dari pemahaman dasar itulah seharusnya diri manusia mengenal dulu karakter genetiknya. Dengan begitu, proses pembentukan diri manusia akan

${ }^{22}$ Tim Dosen Fakultas Tarbiyah UIN Malang, Materi Pendidikan dan Latihan Profesi Guru (Malang: UIN-Maliki Press, 2011), 41.

${ }^{23}$ Agung Purnomo, dkk., Era Genetik (Bekasi: Yayasan Qurrotu A'yun, 2017), ii-iii. 
cenderung tetap, stabil, tidak berubah, fokus, meningkat, dan pada performa terbaiknya. Meski genetik 20\%, namun justru ialah yang paling aktif mencari $80 \%$ lingkungan, sehingga $100 \%$ fenotif itu sejatinya banyak dikontribusi oleh $20 \%$ genetik. Jika faktor genetik sebegitu pentingnya untuk diri manusia ketahui sejak dini demi memudahkan diri manusia menjalani kehidupan -selain tentu saja sebagai wujud rasa syukur terhadap Sang Pencipta atas fitrah genetik yang telah diberikan, maka upaya-upaya untuk menyadarkan umat manusia untuk kembali ke nature, kembali kepada Sang Pencipta perlu dilakukan secara massif. Maka mengenali potensi genetik atau mesin kecerdasan diri manusia cukup mudah. Dengan hanya melakukan scanning kesepuluh jari melalui perosedur Tes STIFIn Fingerprint, dan menunggu hasilnya yang hanya membutuhkan beberapa menit ketika pola-pola sidik jari 'dibaca' oleh komputer, dan akan segera diketahui apakah ber-mesin kecerdasan Sensing, Thinking, Intuiting, Feeling, atau Insting (STIFIn). Dengan demikian, itulah genetika yang mungkin selama ini ada dalam diri yang kemudian seharusnya diasah oleh lingkungan yang tepat sebagaimana rumus STIFIn : "Kenali potensi Genetik, lalu Lingkungan dimaksimalkan untuk mengasah menjadi yang terbaik". ${ }^{24}$

Dengan mengetahui mesin kecerdasan, maka santri akan lebih mudah mengetahui metode menghafal al-Qur'an sesuai dengan potensi masing-masing.

2. Tes Kemampuan Menghafal

Bagi santri Rumah Qur'an STIFIn al-Mawaddah, setelah diterima dan menjalani tahapan tes potensi genetik, maka langkah selanjutnya adalah mengikuti tes kemampuan menghafal, yang mana santri diberi pilihan menghafal, yakni pilihan pertama dalam waktu 8 jam menghafal 5 halaman al-Qur'an dihitung dari jam 06.00 - 13.00, atau dalam waktu 2 jam menghafal 2 halaman al-Qur'an yang dihitung dari jam 07.00 - 09.00 . Apabila ada sebagian santri yang tidak mampu mencapai target, maka akan dilakukan pembiasaan awal selama 1 bulan.

3. Klasifikasi menggunakan teori Sirkulasi STIFIn.

Setelah tes kemampuan menghafal, maka santri diklasifikasikan sesuai dengan mitra kecerdasan antar Pembina dengan santrinya. Dimana dalam pengelompokan disesuaikan dengan teori sirkulasi STIFIn. Lima mesin kecerdasan membentuk sebuah mata rantai segilima mengikuti jarijari tangan kanan yang dimulai dari ibu jari hingga kelingking, bukan mengikuti urutan akronim STIFIn melainkan menggunakan urutan akronim STInIF (sesuai posisi jari tangan), sebagai sebuah aliran sirkulasi yang saling

24 Poniman \& Mangussara, Konsep Palugada (Jakarta : STIFIn Institute, 2013), 12.

Jurnal Pendidikan Agama Islam (Journal of Islamic Education Studies)

Volume 5 Nomor 2 (2017)

ISSN(p) 2089-1946\& ISSN(e) 2527-4511

Hal. 212 - 223 
mendukung. Tipe $\mathrm{S}$ yang rajin mendukung tipe $\mathrm{T}$ yang sistematis. Tipe $\mathrm{T}$ yang terarah mendukung tipe In yang mengalir. Tipe In yang cepat tanggap mendukung tipe I yang banyak ide. Tipe I yang konseptor mendukung tipe F yang visioner. Tipe $\mathrm{F}$ yang pandai memberi semangat mendukung tipe $\mathrm{S}$ yang tahan banting. Selain hubungan saling mendukung, lima MK juga dapat membentuk hubungan bintang lima sudut yang hubungannya saling menaklukkan. Masih memakai pola jari tangan kanan dengan melompati satu mesin kecerdasan: Tipe S yang berstamina mengalahkan tipe In yang nanggung, Tipe In yang responsif mengalahkan tipe F yang banyak omong. Tipe F yang empatik mengalahkan tipe $\mathrm{T}$ yang formal berjarak. Tipe $\mathrm{T}$ yang memiliki kekuatan arah mengalahkan tipe I yang telalu banyak alternatif. Tipe I yang kreatif mengalahkan tipe $\mathrm{S}$ yang peniru.

Dengan mengetahui hubungan saling mendukung dan hubungan saling mengalahkan maka dapat membuat peta hubungan sosial: ideal atau tidak. Prinsip dalam mencari tangan kanan, guru, coach (pelatih), tutor, atau pendukung setia juga hampir sama yakni haruslah yang mendukung atau mundur selangkah (bayangkan segi lima tadi). Lihat contoh ini: tangan kanan tipe $S$ adalah tipe $F$. Tapi prinsip itu tidak belaku jika yang kita cari adalah mentor. Seorang mentor haruslah yang berwibawa atau disegani, dan karenanya haruslah yang menundukkan atau mengalahkan. Sebagai seorang murid, santri tentu tidak mau mentornya kalah pamor. Jadi, kalau memakai prinsip mundur menentang arah jarum jam, maka jika seorang $S$ mencari mentor haruslah I. Sedangkan tipe I mencari mentor yang tipe T. Begitu seterusnya (bayangkan bintang lima sudut) ${ }^{25}$.

\section{Gambar 2: Teori Sirkulasi dan Analogi STIFIn}

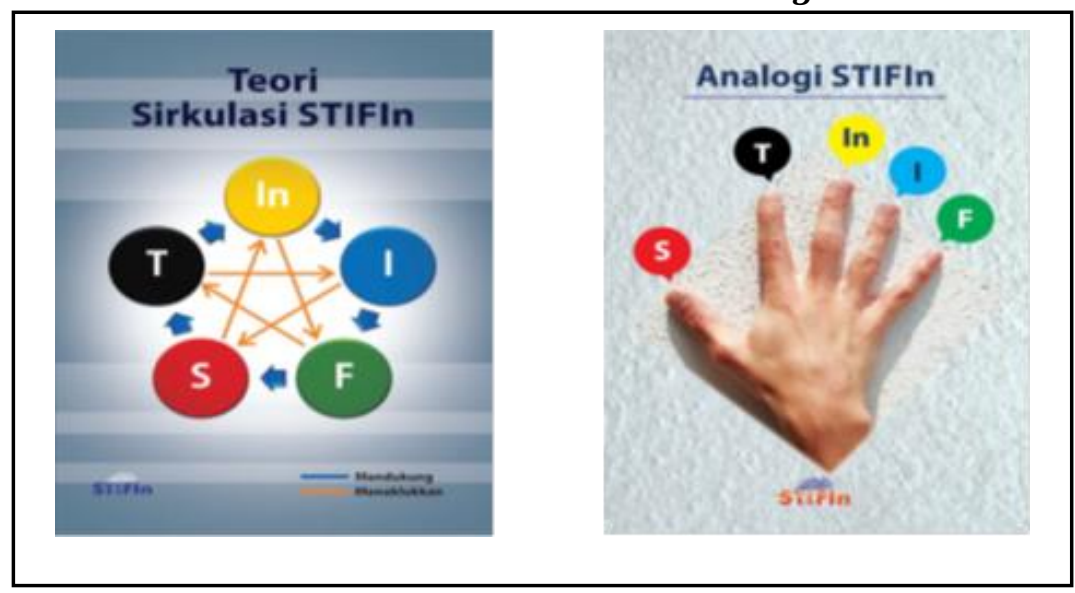

25Poniman \& Mangussara, Konsep Palugada, 27-29. 
4. Setoran hafalan menggunakan Metode STIFIn

Setelah mendapatkan klasifikasi kelompok setoran, maka santri diwajibkan menyetor hafalan minimal 5 halaman perharinya sesuai dengan jadwal yang telah ditentukan. Berikut wawancara dengan Ustadzah Imro'atul Husna, selaku Pengurus Rumah Qur'an STIFIn Al-Mawaddah Paiton Probolinggo:

“Dalam proses setoran hafalan Al-Qur'an santri Rumah Qur'an STIFIn alMawaddah Pondok Pesantren Nurul Jadid dilakukan secara bertahap. Setoran pertama dilakukan pada pukul 06.00-08.30 WIB yang dilanjutkan seotoan kedua pada pukul 09.00-11.00. sedangkan pada pukul 13.00-14.00 dilakukan murojaah dan pukul 16.00-17.30 me-murojaahhafalam $1 / 2$ juz yang telah disetorkan sebelumnya. Selanjutnya rangkaian kegiatan hafalan dengan metode STIFIn ini diikuti dengan Musabaqah Hifdzul Qur'an (MHQ) pada pukul 19.30-20.00 yang bertujuan untuk melatih kemampuan menghafal ayat secara acak.."26

Posisi potensi genetik yang sudah diketahui, pada akhirnya dalam implementasi metode STIFIn memudahkan dan membantu dalam maksimalisasi keakraban dengan al-Qur'an. Dalam implementasinya, masing-masing potensi genetik ini mempunyai cara tersendiri dalam proses menghafal al-Qur'an sebagaimana berikut:27

a. Metode menghafal al-Qur'an bagi tipe sensing

Cara menghafal al-Qur'an bagi tipe sensing yaitu dengan menitikberatkan pada frekuensi pengulangan, mengingat warna, dan tanda. Proses menghafal al-Qur'an bagi tipe sensing adalah sebagai berikut: 28

1) Santri memilih tiga warna. Dalam hal ini santri dibebaskan untuk memilih warna apasaja asalkan kontras satu sama lain. Masingmasing tanda hendaknya menggunakan warna yang berbeda dan konsisten. Gunakan alat tulis untuk memberi tanda berupa warna, lingkaran, dan garis pada bagian ayat yang perlu perhatian khusus, seperti: menandai ra'sul ayat (awal ayat), menandai potongan ayat yang sama dan menandai kata yang sulit diingat, sering tertukar atau sering terlupa.

2) Langkah berikutnya, menandai ra'sul ayat pada setiap ayat di seluruh halaman yang akan dihafalkan pada hari itu. Tandai dengan menebalkan ra'sul ayat dengan bolpoin warna. Hal ini dilakukan di

\footnotetext{
26 Imro'atul Husna, Wawancara, Probolinggo, 24 Desember 2017.

27 Purnomo \& Setiawati, Era Genetik, 45-55.

28 Najla Najmatul Fadhilah, Wawancara, Probolinggo, 23 Desember 2017.

Jurnal Pendidikan Agama Islam (Journal of Islamic Education Studies)

Volume 5 Nomor 2 (2017)

ISSN(p) 2089-1946\& ISSN(e) 2527-4511

Hal. 214 - 223
} 
luar jam menghafal dan akan lebih baik jika dilakukan sebelum sholat subuh.

3) Bacalah 1 halaman al-Qur'an yang akan dihafal sebanyak satu kali dengan terjemahnya. Ini dilakukan untuk sekedar mengetahui makna dari ayat yang akan dihafal. Jika terjemahnya berupa ayatayat perintah, ancaman, atau hukum dapat dengan sekedar mengetahui secara umum saja dan tidak mengingat sambungan ayat dengan mengingat urutan ceritanya.

4) Menandai bagian ayat yang sama dengan bolpoin warna.

5) Membagi satu halaman menjadi dua bagian dan beri tanda batasan di antara keduanya dengan tanda lingkaran kecil berwarna hitam. Pembagian dilakukkan berdasarkan pada jumlah baris, akan tetapi juga disesuaikan dengan akhir ayat, sehingga tidak mutlak pembagiannya 8:7.

6) Selanjutnya santri memulai membaca bagian pertama sambil melihat mushaf sebanyak 20x dan berusaha mengingat ra'sul ayat.

7) Melafalkan tanpa melihat mushaf sebanyak 10 kali dan pada tahpan ini siswa masih diperbolehkan mengintip jika tidak yakin atas pelafalan ayat atau bahkan jika terlupakan.

8) Menandai kata yang sulit atau sering terlupa dengan bolpoin warna dan menggunakan bolpoin berbeda untuk masing-masing penanda.

9) Melafalkan tanpa melihat mushaf sebanyak 10 kali dan pada tahapan ini tidak lagi diperkenankan melihat jika tidak yakin atau lupa.

10) Melanjutkan hafalan pada bagian berikutnya sesuai dengan tahap atau langkah dari 6 (enam) hingga 9 (sembilan).

11) Menggabungkan kedua bagian hafalan tersebut dan melafalkan sebanyak 5 kali tanpa melihat mushaf.

12) Santri menghafalkan halaman kedua sesuai tahapan dari nomor 3 (tiga) hingga 11 (sebelas)

13) Mengulang hafalan kedua halaman tersebut sebanyak 3 kali tanpa melihat mushaf.

14) Langkah teraskhir adalah dengan melakukan setoran hafalan.

b. Metode menghafal al-Qur'an bagi tipe thinking

Cara menghafal al-Qur'an bagi thinkingsebagaimana implementasi metode STIFIn dalam meningkatkan kualitas hafalan di Rumah Qur'an STIFIn Al-Mawaddah Paiton Probolinggo lebih 
menekankan pada target yang ketat dan disiplin pada waktu yang diberikan dan dilakukan dengan: ${ }^{29}$

1) Membagi satu halaman menjadi 3 bagian atau lima baris.

2) Menggunakan alat tulis untuk menandai setiap awal ayat dan akhir ayat.

3) Menggunakan lembar catatan untuk mencatat awal kata ayat dan nomor ayat.

4) Menentukan target waktu untuk menghafal dan membagi waktu 1 jam atau 60 menit menjadi 6 waktu ( 1 waktu $=10$ menit)

5) Membagi 10 (sepuluh) menit pertama menjadi 2 (dua) bagian. Lima menit pertama untuk membaca lafal ayat secara keseluruhan (1 halaman). Kemudian lima menit kedua digunakan untuk membaca terjemahan ayat pada halaman yang selanjutnya diikuti dengan upaya memahami inti dari ayat tersebut.

6) 10 menit kedua santri melakukan proses penghubungan lafal ayat dengan terjemahannya.

7) 10 menit ketiga, mulai menghafalkan lima baris pertama dengan cara mengulang-ulang per baris atau satu baris yang dibagi dua (bagi yang mengalami kesulitan dalam menghafal), sampai lima baris pertama selesai. Hal tersebut dilakukan secara terus-menerus pada lima baris ke dua dan ke tiga.

8) 10 menit keempat, santri menghafalkan lima baris kedua.

9) 10 menit kelima, digunakan untuk menghafal lima baris terakhir.

10) 10 menit terakhir digunakan untuk menggabungkan hafalan dari lima baris pertama hingga akhir

11) Selanjutnya santri menghafalkan halaman kedua dengan cara menghafal halaman pertama.

12) Jika santri tipe thinkingsudah mendapatkan 2 halaman, maka santri tersebut melafalkan 2 halaman tersebut tanpa melihat mushaf sampai lancar selama 30 menit kalau kurang boleh menambah waktu.

c. Metode menghafal al-Qur'an bagi tipe intuiting

Cara menghafal al-Qur'an bagi intuiting sebagaimana implementasi metode STIFIn dalam meningkatkan kualitas hafalan di Rumah Qur'an STIFIn Al-Mawaddah Paiton Probolinggo lebih

\footnotetext{
${ }^{29}$ Najla Najmatul Fadhilah, Wawancara, Probolinggo, 23 Desember 2017.

Jurnal Pendidikan Agama Islam (Journal of Islamic Education Studies)

Volume 5 Nomor 2 (2017)

ISSN(p) 2089-1946\& ISSN(e) 2527-4511

Hal. 216 - 223
} 
menekankan pada daya ingat semantik dan imajinasi cerita dalam memahami terjemah dan dilakukan dengan: ${ }^{30}$

1) Santri dengan tipe ini memulai menghafal dengan membaca terjemahannya atau dibacakan pengertiannya terlebih dahulu kemudian memahami alur ceritanya.

2) Setelah memahami terjemah, santri Rumah Qur'an membaca ayat per ayat dan diulang-ulang sampai hafal. Untuk tipe ini intuiting tidak ada patokan waktu dan lebih mementingkan pengulangan yang dilakukan secara terus-menerus sampai hafal dan lancar.

3) Saat proses menghafal, santri memberi tanda kata-kata yang dianggap sulit dan mirip dengan cara dibulatkan dengan pulpen, pensil, atau dengan stabilo.

4) Dalam proses menghafal al-Qur'an, santri dengan tipe ini tidak akan menghafal sebelum membaca terjemahannya karena dengan membaca terjemahannya intuiting mempunyai daya ingat semantik atau daya ingat berperistiwa.

5) Langlah berikutnya yang dilakukan tipe ini dalam menghafal alQur'an di Rumah Qur'an al-Mawaddah adalah dengan mengekspresikan ketika menghafal dengan mimik muka dan gerakan tangan. Oleh karena itu, tipe ini seringkali walaupun jarang melakukan proses menghafal al-Qur'an di depan cermin agar dapat melihat ekspresi muka sendiri yang nantinya akan memudahkan dalam menghafal.

d. Metode menghafal al-Qur'an bagi tipe feeling

Cara menghafal al-Qur'an bagi tipe feeling sebagaimana implementasi metode STIFIn dalam meningkatkan kualitas hafalan di Rumah Qur'an STIFIn Al-Mawaddah Paiton Probolinggo lebih menekankan pada suasana menghafal yang kondusif (menggunakan kekuatan mendengarnya) dan partner sima'an dan dilakukan dengan: ${ }^{31}$

1) Sebelum menghafal, santri dengan tipe ini terlebih dahulu mendengarkan 10 (sepuluh) kali yang bertujuan untuk mendengarkan murottalayat per ayat dengan menggunakan headset sebanyak 10 (sepuluh) kali tanpa melihat mushaf. Bagi santri yang tidak mempunyai alat bantu, maka guru membacakan ayat per ayat 10 (sepuluh ) kali dan santri mendengarkan dengan seksama,

\footnotetext{
${ }^{30}$ Najla Najmatul Fadhilah, Wawancara, Probolinggo, 23 Desember 2017.

31 Imro'atul Husna, Wawancara, Probolinggo, 24 Desember 2017.
} 
memperhatikan panjang-pendeknya serta cara penempatan waqaf dan cara ibtida' (memulai bacaan setelah waqaf)

2) Santri membaca 10 (sepuluh ) kali (merekam secara visual). Setelah mendengarkan ayat yang akan dihafal, santri dengan tipe ini selanjutnya membaca ayat 10 (sepuluh ) kali dan menghayati makna untuk menghadirkan tokoh/pelaku dalam ayat tersebut sambil mengamati dengan cermat, sehingga memperoleh gambaran menyeluruh tentang lafal \& makna. Dalam proses tersebut, ditekankan untuk membaca dengan benar dan cermat, baik huruf, harakat, panjang-pendeknya, tempat waqaf (berhenti) dan tempat ibtida' (memulai bacaan setelah waqaf) supaya yang masuk ke dalam memori pada fase awal adalah bacaan yang benar. Dalam proses ini, membaca dengan benar akan membantu penghafalan dan pemeliharaan al-Qur'an secara lebih mudah.

3) Membaca dan mendengarkan 10 (sepuluh) kali (merekam secara audio dan praktek secara lisan). Dalam hal ini, santri dengan tipe feeling ini mendengarkan lagi ayat yang dihafalkan sambil mengikuti bacaan sebanyak 10 (sepuluh ) kali.

4) Menghafal 10 (sepuluh ) kali yang dilakukan tanpa mendengarkan murattal dan tanpa melihat mushaf sebanyak 10 (sepuluh ) kali, dengan cara:

a) Menghafal ayat yang telah dihafal dan didengarkan dengan cara sedikit demi sedikit, kalimat per kalimat atau per waqaf, dan diulang-ulang sambil menghayati terjemahannya sebanyak 10 sampai tidak ada kesalahan dan terbayang letak baris dan posisinya. Oleh karena itu, dalam menghafal dianjurkan memakai mushaf pojok dan 1 mushaf yang tetap dan tidak boleh mengganti-ganti mushafyang lain yang berbeda cetakan karena posisi kalimat pada ayat dalam suatu mushafyang berbeda antar satu cetakan dan yang lain cetakan.

b) Setelah kalimat-kalimat pada ayat tersebut dapat dihafalkan oleh santri tipe feeling dengan lancar, dantri tersebut kemudian menambah hafalan pada kalimat selanjutnya dengan cara yang sama dan kemudian merangkaikannya sehingga sempurna sampai satu ayat. Selanjutnya langkah dan cara menghafal santri tipe feeling iniadalah merangkaikan kalimat pada ayat dengan diulang-ulang sampai benar-benar hafal tanpa ada kesalahan. 
c) Setelah selesai menghafal satu ayat dengan lancar, santri tipe feeling baru kemudian boleh berpindah pada ayat selanjutnya dengan cara sebagaimana pada poin 1,2,3,4.

d) Untuk merangkaikan hafalan urutan kalimat dan ayat dengan benar, maka santri dengan tipe feeling setiap kali selesai menghafal kalimat atau ayat berikutnya, mereka mengulang minimal sebanyak 10 (sepuluh) kali. Misalnya: ayat pertama dirangkaikan ke ayat ke dua dan diulang-ulang minimal sebanyak 10 (sepuluh) kali, lalu dirangkaikan pada ayat ke tiga 10 (sepuluh) kali dan begitu seterusnya. Namun, ada juga santri yang pengulangannya dilakukan dengan urutan mundur, misalnya: ayat terakhir dirangkaikan dengan ayat ke dua terakhir, kemudian mengulang dimulai ayat kedua terakhir baru dirangkaikan dengan ayat di atasnya atau sebelumnya dan begitu seterusnya, hingga satu halaman diulang lagi minimal 10 (sepuluh) kali sampai tidak ada kesalahan baik dari sisi pelafalan maupun urutan ayat-ayatnya.

e) Jika menemukan dalam proses menghafal ditemukan lafal-lafal yang sulit dihafal, karena serupa atau yang hampir serupa dengan lafal lain, maka santri dengan utipe feeling ini memperhatikan secara khusus, mencermati, dan menghayati maknanya, dan selalu mengulang-ulang. Begitu pula dengan penutup atau ujung setiap ayat perlu yang mendapat perhatian secara cermat dan bahkan memberi tanda tertentu jika dianggap perlu.

f) Setelah menghafal satu halaman dengan baik dan lancar, maka santri dengan tipe feeling ni melanjutkan menghafal halaman berikutnya dengan memulainya dari poin 1,2,3 dan 4 .

g) Dalam hal merangkai halaman, santri tipe feeling dalam implementasi metode STIFIn memperhatikan sambungan akhir halaman tersebut dengan awal halaman berikutnya, sehingga hafalan tersebut sambung-menyambung. Dengan demikian, setiap selesai satu halaman santri tpe feeling melakukan pengulangan dengan merangkaikan pada halaman-halaman berikutnya.

h) Begitu seterusnya dari kalimat per kalimat, ayat per ayat, halaman per halaman. Dalam implementasi metode STIFIn bagi santri tipe feeling yang tidak boleh terputusdan harus 
dirangkaikan, dicermati maknanya, dan diulang-ulang terus minimal 10 (sepuluh) kali hingga terekam di memori otak.

5) Tasmi' (hafalan disimak orang lain) sebanyak 5 (lima) kali Dalam implementasi metode STIFIn bagi tipe feeling, setelah proses menghafal hafalan minimal dua halaman, maka berikutnya dapat diperdengarkan hasil hafalan tersebut pada teman untuk mengetahui mengoreksi kelancarannya. Setelah hafalan benar-benar baik dan lancar, santri dengan tipe feeling baru diperkenankan menghadap kepada guru untuk ditashih-kan (disimak dan dibetulkan) hafalannya serta mendapat petunjuk dan bimbingan seperlunya. Langkah tasmi' ini dalam prakteknya juga diikuti dengan tasmi' materi hafalan yang pertama. Jadi, pada proses tasmi' bukan hanya materi hafalan kedua saja yang ditashih, akan tetapi materi hafala yang pertama juga ditashih saat itu. Setelah setor baru diawali dengan menyetor materi lama minimal 10 halaman dan maksimal 20 halaman, atau disetorkan pada program muraja'ah/takrir.

e. Metode menghafal al-Qur'an bagi tipe insting

Cara menghafal al-Qur'an bagi tipe insting sebagaimana implementasi metode STIFIn dalam meningkatkan kualitas hafalan di Rumah Qur'an STIFIn Al-Mawaddah Paiton Probolinggo lebih menekankan pada lingkungan yang tenang dan penggunaan keserbabisaannya dalam menghafal. Adapun cara menghafal bagi tipe ini dalam implementasi metode STIFIn adalah sebagai berikut: ${ }^{32}$

1) Santri dengan tipe insting dalam proses menghafal diperkenankan mencari tempat yang dianggap tenang, kondusif dan jauh dari keramaian. Bagi santri penghafal al-Qur'an dengan tipe ini, tempat yang tenang dan jauh dari keramaian merupakan hal yang penting karena orang insting akan merasa nyaman ketika berada dalam ketenangan dan jauh dari konflik. Kenyamanan akan memudahkan insting untuk meresap dan mengahafal segala informasi (dalam hal ini al-Qur'an). Mereka akan kesulitan dalam berkonsentrasi jika tempat dan suasana kurang kondusif. Emosi mereka pun mudah meluap jika ada gangguan berupa kegaduhan dari sekitarnya sehingga dapat merusak mood mereka ketika menghafal.

2) Dalam implementasi metode STIFIn bagi tipe insting, menggunakan semua pintu keserbabisaan merupakan hal yang dianjurkan, yang

${ }^{32}$ Najla Najmatul Fadhilah, Wawancara, Probolinggo, 23 Desember 2017.

Jurnal Pendidikan Agama Islam (Journal of Islamic Education Studies)

Volume 5 Nomor 2 (2017)

ISSN(p) 2089-1946\& ISSN(e) 2527-4511

Hal. 220 - 223 
dalam hal yaitu dengan menggunakan pendengaran, penglihatan, dan gerakan tubuh. Demikian pula dengan mendengarkan nada murattal atau qira'at juga dianjurkan untuk membantu mempermudah dalam menghafal karena tipe instingini memiliki kecerdasan musical. Berikut adalah pintu keserbabisaan yang dapat digunakan oleh tipe ini:

a. Daya pikir: dilakukan dengan memfokuskan pikiran dengan membaca terjemahan dan memahami makna dari setiap ayat yang tengah dihafal.

b. Penglihatan: dilakukan dengan menghafal letak dan posisikata dalam setiap ayat.

c. Gerakan tubuh: dilakukan oleh tipe insting ini ketika tengah menerjemahkan ayat dengan menggunakan bantuan gerakan tubuh untuk mengekspresikanmakna yang terkandung dalam ayat.

3) Langkah berikutnya bagi tipe ini adalah dengan menghafal per ayat dari setiap halaman.

4) Berikutnya santri tipe insting menggunakan formula 20 :

a. 20 (dua puluh) kali membaca dengan khusyu' dan tawadhu' satu halaman penuh.

b. 20 (dua puluh) kalimembaca per ayat dengan merekam (menghafal)

c. Melakukan penggabungan ayat setiap selesai menghafal ayat baru. Setiap selesai satu ayat lanjut ke ayat kedua. Ayat pertama dan kedua digabung dan dibaca 10 (sepuluh) kali. setelah lancar, maka santri dengan tipe insting ini melanjutkan ke ayat ketiga yang kemudian digabung ayat pertama sampai ketiga dengan pengulangan 3 sampai 10 (sepuluh) kali dan seterusnya hingga sampai akhir halaman.

d. 10 (sepuluh) kali muraja'ah bil ghaib ( mengulang tanpa melihat mushaf) sampai benar-benar lancar dan baru dilanjutkan ke halaman berikutnya.

Untuk mengoptimalkan penggunaan metode tersebut, maka diadakan pembinaan dan pendalaman konsep STIFIn oleh Mudir Rumah Qur'an STIFIn pusat setiap 1 bulan 1 kali untuk merefresh pengetahuan terhadap konsep STIFIn.

Demikianlah Rumah Qur'an STIFIn Al-Mawaddah Paiton, Probolinggo dalam upayanya untuk dapat mengimplementasikan metode 
STIFIn dalam menghafal Al-Qur'an. Paling tidak, santri dapat menghafal dengan baik dan nyaman. Para guru pembina mengharapkan dengan metode STIFIn tersebut santri dapat menyelesaikan hafalannya dengan cepat namun sulit untuk dilupakan.

\section{E. Kesimpulan}

Berdasarkan uraian di atas, menunjukkan bahwa implementasi metode STIFIn dalam meningkatkan kemampuan menghafal al-Qur'an di Rumah Qur'an STIFIn Al-Mawaddah Paiton Probolinggo dilakukan dengan; pertama, pemetaan potensi penghafal al-Qur'an dengan tes potensi genetik. Tes genetik ini dilakukan dengan tes sidik jari atau DNA sehingga dapat dikatakan bahwa pemetaan potensi santri dilakukan berdasarkan teori hereditas. Berdasarkan tes tersebut dapat diketahui potensi genetik siswa apakah mempunyai potensi genetik tipe thinking, intuiting, feeling, atau insting (STIFIn). Berdasarkan potensi yang tentunya berbeda antar masing-masing tersebut, maka akan memudahkan melakukan "rekayasa" dalam pembelajaran termasuk dalam menghafal alQur'an; kedua, tes kemampuan menghafal dengan cara diberi pilihan 8 (delapan) jam atau 2 (dua) jam dengan target jumlah hafalan yang berbeda pada kedua pilihan; ketiga, proses klasifikasi yang berbasis pada teori STIFIn. Dalam hal ini, santri diklasifikan sesuai dengan mitra kecerdasan antar pembina masingmasing santri. Lima mesin kecerdasan membentuk sebuah mata rantai segi lima mengikuti jari-jari tangan kanan yang dimulai dari ibu jari hingga kelingking, bukan mengikuti urutan akronim STIFIn melainkan menggunakan urutan akronim STInIF (sesuai posisi jari tangan); dan keempat, dengan melakukan setoran hafalan yang berbasis pada konsep STIFIn. Dalam konsep STIFIn, masing-masing santri penghafal al-Qur'an yang mempunyai potensi genetik yang berbeda, menghafal dan menyetorkan apa yang mereka hafalkan minimal 5 (lima) halaman per hari, yang kemudian diakhiri dengan kegiatan Musabaqah Hifdzul Qur'an (MHQ) untuk melatih kualitas hafalan yang dilakukan secara acak.

\section{F. Referensi}

Bakir, R. Suyoto. Kamus Lengkap Bahasa Indonesia. Batam: Karisma Publishing Group, 2006.

Bhinnety, Magda. "Struktur dan Proses Memori." Buletin Psikolgi, 2008.

Chairani, Lisya, dan Subandi, M.A. Psikologi Santri Penghafal Al-Qur'an. Yogyakarta: Pustaka Pelajar, 2011.

Daradjat, Zakiyah. Metodologi Pengajaran Agama Islam. Jakarta: Bumi Aksara, 1996. 
Djamarah, Syaiful Bahri. Guru dan Anak Didik dalam Interaksi Edukatif. Jakarta: Rineka Cipta, 2010.

Poiniman, Farid, dan Mangussara, Rahman Adi. Konsep Palugada. Jakarta: STIFIn Institute, 2013.

Poniman, Farid, Nugroho, Indrawan., dan Azzaini, Jamil. Kubik Leadership. Jakarta: Gramedia Pustaka Utama, 2008.

Pribadi, Benny A. Model DEsain Sistem Pembelajaran. Jakarta: Dian Rakyat, 2011.

Prihantini, Gita Sekar. Strategi Belajar. Malang: UMM Press, 2015.

Purnomo, Agung dan Setiawati, Rina, Era Genetik. Bekasi: Yayasan Qurrotu A'yun, 2017.

Sanjaya, Wina. Strategi Pembelajaran Berorientasi Standar Proses Pendidikan. Jakarta: Kencana, 2006.

Sunhaji. Pembelajaran Tematik Integratif Pendidikan Agama Islam dan Sains. Purwokerto: STAIN Press, 2013. . Strategi Pembelajaran. Purwokerto: STAIN Press, 2012.

Syahin, Abdul Shabur. Saat al-Qur'an Butuh Pembelaan. Jakarta: Erlangga, 2006.

Tim Dosen Fakultas Tarbiyah UIN Malang. Materi Pendidikan dan Latihan Profesi Guru (PLPG). Malang: UIN Press, 2011.

Tim Penyusun Kamus Pusat Pembinaan dan Pengembangan Bahasa. Kamus Besar Bahasa Indonesia. Jakarta: Balai Pustaka, 1989.

Tirmidzi (al), Abi Isa. Jami' al-Tirmidzi. Riyadl: Bait al-Afkar, t.t.

Wiyani, Ardi, Novan, dan Bernawi. Ilmu Pendidikan Islam; Rancang Bangun Konsep Pendidikan Monokotomik-Holistik. Yogyakarta: Ar-Ruzz Media, 2012. 